Jurnal Ilmu dan Teknologi Kesehatan

Vol 9, No 1, Sept 2021

ISSN: 2338-9095 (Print)

ISSN: 2338-9109 (online)

\title{
The Effect of Antenatal Care During Covid -19 on Complications of Pregnant
}

\author{
Ni Gusti Made Ayu Agung Budhi*, Maryanah \\ Midwifery Department Poltekkes Kemenkes Jakarta III, Indonesia \\ *Email: nigmaryana@gmail.com
}

\section{Article history \\ Posted, Jul $14^{\text {th }}, 2021$ \\ Reviewed, Aug $23^{\text {th }}, 2021$ \\ Received, Sep $4^{\text {th }}, 2021$}

\begin{abstract}
Quality Antenatal Care (ANC) services can prevent complications during pregnancy, but during the Covid-19 pandemic, there is a policy for mothers to postpone ANC visits. The purpose of the study was to find out how the influence of ANC services during the Covid-19 pandemic on the incidence of complications in pregnant women. The research method used is an analytical survey with a Cross-Sectional approach. The number of samples is 110 pregnant women respondents. The statistical test used is the Chi-Square test. The results showed that the age of pregnant women was $92.1 \%$ of healthy reproductive age, high school education level was $90.4 \%$, some pregnancies experienced by mothers 2 were $66.7 \%$, work as housewives were $67 \%$. The biggest complication that occurs in pregnant women is anemia (40\%). The provision of quality ANC services with 10T has a positive influence on the incidence of complications in pregnancy during the pandemic (p-value <0.05), as well as understanding of the Maternal and Child Health $(\mathrm{MCH})$ book ( $p$-value <0.05) and the anxiety felt by the mother ( $p$-value <0.05) influences the occurrence of complications. The conclusions obtained were the effect of providing quality ANC services with $10 \mathrm{~T}$, understanding of the MCH handbook on the incidence of complications during the covid-19 pandemic.
\end{abstract}

Keywords: antenatal care; Covid -19 pandemic; MCH handbook; pregnancy complications

\begin{abstract}
ABSTRAK
Pelayanan Antenatal Care (ANC) yang berkualitas dapat mencegah terjadinya komplikasi selama kehamilan, namun di masa pandemi Covid-19 terdapat kebijakan ibu untuk menunda kunjungan ANC. Tujuan dari penelitian adalah mengetahui bagaimana pengaruh layanan ANC di masa pandemi Covid-19 terhadap kejadian komplikasi pada ibu hamil. Metode penelitian yang digunakan survei analitik dengan pendekatan Cross Sectional. Jumlah sampel sebesar 110 responden ibu hamil. Uji statistik yang digunakan adalah uji Chi Square. Hasil didapatkan bahwa usia ibu hamil adalah usia reproduksi sehat 92,1\%, tingkat pendidikan $\geq$ SMA sebesar $90,4 \%$, jumlah kehamilan yang dialami ibu $\leq 2$ sebesar $66,7 \%$, pekerjaan sebagai ibu rumah tangga $67 \%$. Komplikasi terbesar yang terjadi pada ibu hamil adalah anemia (40\%). Pemberian pelayanan ANC berkualitas dengan $10 \mathrm{~T}$ memiliki pengaruh positif terhadap kejadian
\end{abstract}


komplikasi dalam kehamilan selama masa pandemi ( $p$-value $<0,05)$, begitu pula dengan pemahanan terhadap buku Kesehatan Ibu dan Anak (KIA) (p-value <0,05) dan adanya kecemasan yang dirasakan ibu ( $p$-value <0,05) memiliki pengaruh terhadap terjadinya komplikasi. Simpulan yang didapatkan adanya pengaruh pemberian layanan ANC berkualitas dengan $10 \mathrm{~T}$, pemahaman terhadap buku KIA terhadap kejadian komplikasi selama masa pandemi Covid-19.

Kata kunci: antenatal care; pandemi Covid-19; buku KIA; komplikasi kehamilan

\section{INTRODUCTION}

Maternal mortality is still a concern of the Indonesian government. The maternal mortality rate in Indonesia in 2015 was 305 per 100,000 live births. This figure is still far from achieving the 2015 Millennium Development Goals (MDGs) target of 102 per 100,000 live births (Kementerian Kesehatan Republik Indonesia, 2019). Based on the Jakarta Health Department report in 2018, 27 cases of maternal mortality of 52,781 live births in East Jakarta. Maternal mortality occurred as many as four people during pregnancy, during the delivery period six people, and the postpartum period as many as 17 people (Badan Pusat Statistik Provinsi DKI Jakarta, 2019).

Maternal hemorrhage constitutes $39.7 \%$ of all major causes of maternal death in pregnant women, childbirth, and the puerperium. In East Jakarta, the causes of maternal death were bleeding in 10 cases, hypertension in 7 cases, and 10 cases due to metabolic disorders and others (Badan Pusat Statistik Provinsi DKI Jakarta, 2019).
The government's efforts to accelerate the reduction in maternal mortality can be seen in the SDGs program in the first three points. The goal set is that by 2030 the MMR is expected to decrease to 70 per 100,000 KH (Ermalena, 2017). Seven Main Programs include; Provision of Maternal and Child Health (KIA) services at the village level according to standards; Provision of health care facilities at the basic level that is capable of providing standardized delivery assistance 24 hours 7 days a week; Guarantee entire public health care centers, community health centers Neonatal Basic Emergency Obstetric Care (PONED) and Comprehensive Emergency Obstetric Neonatal Service Hospital (PONEK Hospital) for 24 hours 7 days a week function according to standards; Implementation of effective referral in cases of complications; Strengthening district/city governments in decentralized health program governance, such as regulation, financing, and others; Implementation of cross-sector and private partnerships; Increase behavior change and community empowerment through 
understanding and implementing Birth Planning and Complication Prevention Program and Integrated maternal and child health services (Nurhidajat and Kusumawati, 2018).

During the Covid-19 pandemic, the current implementation of the maternal mortality rate reduction program encountered a few obstacles in health services, especially in antenatal care, intra-natal care, and postnatal care services. Where pregnant women must be able to monitor their pregnancy through the maternal and child health book, this is where the role of families and cadres is needed in helping mothers recognize the health conditions of the mother and the fetus (Kementerian Kesehatan RI, 2020). Besides, the mother's ability to recognize danger signs in pregnancy and childbirth will be very helpful in the early detection of complications. So that mothers and families will be able to find the right help at the right time. Thus delays in making decisions can be prevented, and in the end, the mother will get immediate help. Severe conditions at the time of referral may be avoided. Delay in referral will greatly affect the final result of handling (Budhi and Nurhayati, 2020).

Pregnancy service programs in health facilities at the Midwife's Independent
Practice (PMB), public health care centers (Puskesmas), Maternity Clinics, and Hospitals are limited to reduce the transmission of Covid -19. Health services for pregnant women, childbirth, postpartum, and newborns during the COVID-19 pandemic are held by considering the prevention of transmission of the coronavirus for both mothers, babies, and health workers. The limitation of antenatal care and prenatal care examination visits was balanced by telecommunication between individual health workers and mothers and organizing online Mother Classes. Health workers must strengthen the ability of mothers and families to understand the Maternal and Child Health (MCH) Handbook to recognize danger signs and apply care during pregnancy and postpartum in everyday life. The guidelines state that health services for pregnant women during a pandemic must also be of high quality (Kementerian Kesehatan RI, 2020).

Midwifery care provided to pregnant women is expected to be in accordance with guidelines during the covid pandemic to prevent mothers from pregnancy complications by recognizing the danger signs of pregnant women listed in the $\mathrm{MCH}$ handbook and reducing maternal anxiety levels. But research on the effect of ANC 
services during the Covid-19 pandemic on the incidence of complications in pregnant women is still limited. Based on the description above, the authors are interested in researching Antenatal Care Services carried out by midwives at the Midwife Independent Practice (MIP) Durensawit District during the covid pandemic on the incidence of complications in pregnant women conducted by direct interviews with pregnant women during visits to midwives.

\section{METHOD}

This study used a survey method with a cross-sectional approach. The research subjects were pregnant women. The population was all pregnant women who conducted examinations at 3 Independent Midwives Practices (PMB) in the East Jakarta area, namely PMB Midwife Kopsah, SST., Midwife Cut Meliana Suri, Amd. Keb and Midwife Hj Sutrianah, SST. The number of samples is calculated based on the sample size formula using the formula Lemeshow as many as 110 respondents. The sampling method used in this study used a purposive consecutive sampling design. This research was started from February to November 2020. The variables that will be studied in this study are the characteristics of the mother (mother's age, education, parity, and mother's occupation), complications experienced by the mother, the number of antenatal care visits seen from the first and fourth visits during pregnancy, providing antenatal care services based on the $10 \mathrm{~T}$ standard, understanding maternal and child health books, family involvement in providing delivery care, providing information on Covid prevention by midwives. $10 \mathrm{~T}$ include: weigh and measure height, blood pressure check, assess nutritional status (measure upper arm circumference), examination of height of the uterine fundus, determine fetal presentation and fetal heart rate, screening for Tetanus immunization status and administering Tetanus Toxoid (TT) immunization if needed, administration of iron tablets of at least 90 tablets during pregnancy, laboratory tests (routine and special), case management, and interviews (counseling), including birth planning and complications prevention and post-delivery family planning.

The time of data collection started from August to October 2020. This analysis was calculated using statistical tests using the Chi-Square method. This research has passed the Health Research Ethics Commission of Jakarta III Health Polytechnic's ethical clearance with the number KEPK-PKKJ3/S.130/XI/2020. The research process is carried out by providing 
research information sheets, research approval sheets, including the rights of respondents in this study. The calculation results of the minimal sample size are 110 respondents. In this study, there was a change in data retrieval, which initially would be carried out by interview, but at the end of this study using a google form application in data retrieval. From the results of editing the 120 data entered, it was found that only 114 data could be used because some data were declared incomplete, and there were duplicate data.

\section{RESULTS AND DISCUSSION}

Since the end of February 2020 has been the Covid-19 pandemic period until now. There are several changes in health services for pregnant women, childbirth, postpartum, and newborns adjusted to the situation. Posyandu program, maternity classes are temporarily abolished, and ANC visits are conducted effectively according to the agreement. It is done to reduce transmission to pregnant women (Kementerian Kesehatan RI, 2020). Most pregnant women are educated $\geq$ in high school by
90.4\% (103 people). Maternal parity is mostly $66.7 \%$ (76 people) are pregnant women $\leq 2$ (first and second child) and most $67 \%$ (65 people) are housewives. From the results of univariate data analysis on maternal characteristics data collected in this study, it was found that the ages of pregnant women are mostly the age of healthy reproduction of 20 years to 35 years of age by $92.1 \%$ (105 people). Most pregnant women are educated $\geq$ in high school by $90.4 \%$ (103 people). Maternal parity is mostly $66.7 \%$ (76 people) are pregnant women $\leq 2$ (first and second child) and most $67 \%$ (65 people) are housewives.

From the results of the bivariate analysis on the characteristics of pregnant women in this study, it was found that maternal occupation influenced complications in pregnancy with a p-value $<0.05$ with odds ratios of 2.426 and $(\mathrm{CI}=0.979-6.011)$. Meanwhile, age, level of education, and parity of pregnant women do not affect pregnancy complications with $\mathrm{p}$-value $>0.05$ as illustrated in table 1 below. 
Table 1. Characteristics of Respondents to Complications of Pregnancy during the Covid-19 Pandemic $(n=114)$

\begin{tabular}{|c|c|c|c|c|c|c|}
\hline \multirow[t]{2}{*}{ Maternal characteristics } & \multicolumn{2}{|c|}{$\begin{array}{c}\text { No } \\
\text { Complication }\end{array}$} & \multicolumn{2}{|c|}{$\begin{array}{c}\text { With } \\
\text { Complication }\end{array}$} & \multirow[t]{2}{*}{ P-value } & \multirow[t]{2}{*}{$95 \% \mathrm{CI}$} \\
\hline & $\mathrm{F}$ & $\%$ & $\mathrm{~F}$ & $\%$ & & \\
\hline \multicolumn{7}{|l|}{ Ages of pregnant women healthy } \\
\hline $\begin{array}{l}\text { Reproductive ages (20 years- } 35 \\
\text { years) }\end{array}$ & 81 & 91 & 24 & 96 & \multirow[t]{2}{*}{0.37} & \multirow[t]{2}{*}{$\begin{array}{c}0.422 \\
(0.05-3.544)\end{array}$} \\
\hline $\begin{array}{l}\text { Reproduction is not healthy } \\
(<20 \text { years }->35 \text { years })\end{array}$ & 8 & 9 & 1 & 4 & & \\
\hline \multicolumn{6}{|l|}{ Education } & \multirow{3}{*}{$\begin{array}{c}3.038 \\
(0.37-24.952)\end{array}$} \\
\hline$\leq$ Junior high school & 10 & 11 & 1 & 4 & 0.279 & \\
\hline$\geq$ Senior high school & 79 & 89 & 24 & 96 & & \\
\hline \multicolumn{7}{|l|}{ Parity } \\
\hline Gravida $\leq 2$ & 56 & 63 & 20 & 80 & \multirow{2}{*}{0.084} & 0.424 \\
\hline Gravida $\geq 3$ & 33 & 37 & 5 & 20 & & $(0.145-1.237)$ \\
\hline \multicolumn{7}{|l|}{ Occupation } \\
\hline maternal housewives & 55 & 62 & 10 & 40 & \multirow[t]{2}{*}{0.043} & 2.426 \\
\hline maternal works & 38 & 38 & 15 & 60 & & $(0.979-6.011)$ \\
\hline
\end{tabular}

Most of the ages of pregnant women in this study were $92.1 \%$ (105 people) were of healthy reproductive age aged 20 years to 35 years. It is in line with several studies where most respondents are of childbearing age (Ariestanti, Widayati and Sulistyowati, 2020). Healthy reproductive age is the age that is almost ready to face pregnancy, both physically and mentally. The reproductive function at this age is the best where the female reproductive organs are completely ripe and ready to receive the fruit of her pregnancy to minimize complications in pregnancy (Nurhidajat and Kusumawati, 2018).

This high enough education can make it easier for mothers to receive the knowledge conveyed by midwives to carry out pregnancy care independently and make decisions when complications occur (Ariestanti, Widayati and Sulistyowati, 2020). The level of a mother's knowledge of pregnancy danger signs is one of the nonmedical factors, which can accelerate the reduction of maternal morbidity and mortality. However, in this study, there was no effect of the level of education of pregnant women on the incidence of complications. There is no effect of the education level of pregnant women on the incidence of complications in this study. Most (88.8\%) pregnant women have a high school education level and above so that mothers can find information on their health through the internet and get information from midwives through telecommunications. Previous experience 
of pregnant women will also affect the level of knowledge of mothers in care during pregnancy. In addition, pregnancy complications occur because the mother has risk factors such as being too young or too old to give birth, her medical history, especially obstetric medical history. Indonesian culture generally believes that mothers have the main task of caring for children, families and taking care of the house. Although not all of these opinions can be accepted, they are still widely applied in Indonesia (Putri and Lestari, 2015).

In this study, the mother's occupation affects the incidence of pregnancy complications with a p-value $<0.05$ and has a risk of $2.426(0.979-6.011)$ in working mothers experiencing complications in pregnancy. It is in line with the research of Masturoh, Respatih and Murti (2017), which states that maternal work has a significant correlation with maternal mortality with a p-value $<0.05$ with a risk of 2.06; 95\% CI (1.06 -6.28). Mother's work is an important factor in knowing the danger signs of pregnancy, which working mothers know better than housewives. Pregnant women who work can tell each other about their experiences during pregnancy. From this discussion, working pregnant women can better understand the complications that occur in pregnancy by introducing the danger signs they experience (Jewaro et al., 2020). One of the factors in maternal mortality is four too, namely too old, too young, too frequent childbirth, too short birth spacing (Nurhidajat and Kusumawati, 2018). In this study, the parity factor is also a characteristic of the mothers studied. However, the maternal parity analysis results on the occurrence of complications did not affect with $p$ value $>0.05$. Several studies have shown that more parity is a factor in maternal mortality (Sulastri et al., 2019).

The parity factor of the mother having the number of children mainly was less or equal to 2 (low risk of pregnancy) in this study. The parity analysis of the mother on the occurrence of complications did not affect the $\mathrm{p}$ value $>0.05$. Several studies have shown that more parity is a factor in maternal mortality. The number of parity in Grande multiparity or maternal pregnancies of more than 4 has a higher risk than mothers who only have a history of parity less than 4. There were 25 pregnancy complications in this study consisting of anemia, hyperemesis gravidarum, preeclampsia, young and old pregnant bleeding (low placenta), fetal abnormalities in the form of breech presentation, IUGR, large babies, as illustrated in table 2. 
Table 2. Pregnancy Complications in 3 Midwives Independent Practices District Durensawit, East Jakarta

\begin{tabular}{lcc}
\hline \multicolumn{1}{c}{ Diagnosis } & Frequency & Percentage \\
\hline Anemia & 10 & 40 \\
\hline Hyperemesis Gravidarum & 7 & 28 \\
\hline Early pregnant bleeding & 1 & 4 \\
\hline Placenta previa & 1 & 4 \\
\hline Preeclampsia & 1 & 4 \\
\hline Other illnesses (fever and cough) & 2 & 8 \\
\hline Fetal abnormalities: & 1 & 12 \\
$\quad$ IUGR & 1 & \\
Giant Baby & 1 & 100 \\
Breech presentation & 25 &
\end{tabular}

Direct causes and indirect causes cause maternal mortality based on ICD-10. The direct causes of maternal mortality in Indonesia are caused by the classic triad of bleeding, hypertension in pregnancy, and infection. However, there are other causes, such as prolonged labor and unsafe abortion. It is indirectly caused by low maternal health statuses such as anemia, low nutritional status, chronic comorbidities such as heart disease, tuberculosis, malaria, and poor reproductive status (Achadi, 2019); Nurhidajat and Kusumawati, 2018). In this study, complications of anemia (40\%) and hyperemesis gravidarum (28\%), abnormalities in the fetus (IUGR, large babies and breech presentation by $12 \%$ ), and fever and cough (8\%) bleeding in young pregnant and placenta previa and preeclampsia (4\% or one incidence each). Anemia became the most significant complication that often occurred in this study. Although anemia is not a direct cause of maternal death, anemia can cause bleeding, prolonged childbirth, IUGR, and reduced quality of life (Achadi, 2019). Hyperemesis gravidarum is also a complication of pregnancy in the first and second trimesters before 20 weeks gestation. Hyperemesis gravidarum can worsen the mother's condition if not immediately corrected, and complications are well detected. Hyperemesis gravidarum is mainly caused by maternal psychology. It is in line with this study that maternal anxiety influences the incidence of complications.

Data in East Jakarta, the highest maternal cause of death is bleeding with 10 cases followed by hypertension in pregnancy 7 cases and other concomitant diseases as many as 10 cases. But the coverage of pregnancy complications reached $93.6 \%$ (Badan Pusat Statistik Provinsi DKI 
Jakarta, 2019). Therefore, quality ANC services according to health standards and promotion through counseling of pregnancy danger signs by health workers (midwives) are very important. ANC services carried out during the Covid-19 period in this study showed that most of the respondents visited pregnant women following the government program from the first antenatal care visit (K1) to the fourth pregnancy check-up visit (K4) carried out according to $86 \%$ (98 people).

Maternity care or antenatal care services with the principle of $10 \mathrm{~T}$ are mostly not provided following the standard of $10 \mathrm{~T}$ of $61.4 \%$ (70 people). The understanding of pregnant women about the care of pregnant women in the $\mathrm{MCH}$ handbook has largely understood its content by $82.5 \%$ (94 people). The family's involvement in the provision of pregnancy care to the mother as large as $88.6 \%$ (101) already involves the husband or family. In providing information on the prevention of pregnant women against Covid-19 disease, a large $78.1 \%$ (89 people) have been given midwives. As a large pregnant woman who felt anxious during the Covid-19 pandemic, it amounted to $50.9 \%$ (58 people).

The results of the bivariate analysis of the quality of ANC services during the Covid19 period obtained that the number of ANC visits, family involvement in providing care for pregnant women, the provision of Covid-19 prevention information by midwives did not affect the incidence of complications. Pregnant women in East Jakarta in 2020 with a value of $p>0.05$. The quality of service with the 10T program, the understanding of pregnant women about $\mathrm{MCH}$ handbooks, and the existence of anxiety statements due to the condition of the Covid-19 pandemic affect the occurrence of complications in pregnant women with a value of $\mathrm{p}<0.05$. However, table 3 also shows the quality of 10T services provided to pregnant women. Understanding $\mathrm{MCH}$ handbooks, especially in the care of pregnant women, can reduce complications in pregnant women by $0.233(0.074-0.735)$ and 0.251 (0.080 - 0704). 
Table 3. The Effect of ANC Services during the Covid-19 Period on Complications in Pregnant Women in the East Jakarta Region in 2020 ( $n=114)$

\begin{tabular}{|c|c|c|c|c|c|c|}
\hline \multirow[t]{2}{*}{ ANC Service Components } & \multicolumn{2}{|c|}{$\begin{array}{c}\text { No } \\
\text { Complication }\end{array}$} & \multicolumn{2}{|c|}{$\begin{array}{c}\text { With } \\
\text { Complication }\end{array}$} & \multirow[t]{2}{*}{$\begin{array}{c}\text { P- } \\
\text { value }\end{array}$} & \multirow[t]{2}{*}{$95 \%$ CI } \\
\hline & $\mathrm{F}$ & $\%$ & $\mathrm{~F}$ & $\%$ & & \\
\hline \multicolumn{7}{|l|}{$\begin{array}{l}\text { Number of Visits of } \\
\text { pregnant women (K1-K4) }\end{array}$} \\
\hline According to the program & 79 & 89 & 19 & 76 & 0.104 & 0.401 \\
\hline $\begin{array}{l}\text { No According to the } \\
\text { program }\end{array}$ & 10 & 11 & 6 & 24 & & $(0.13-1.24)$ \\
\hline \multicolumn{7}{|l|}{ Service standard $10 \mathrm{~T}$} \\
\hline Awarded 10T & 40 & 45 & 4 & 16 & 0.009 & 0.233 \\
\hline Less than <10T & 49 & 55 & 21 & 84 & & $(0.074-0.735)$ \\
\hline \multicolumn{7}{|l|}{$\begin{array}{l}\text { Understanding of the } \\
\text { MCH handbook }\end{array}$} \\
\hline Understand & 78 & 68 & 16 & 64 & 0.006 & 0.251 \\
\hline No, understand & 11 & 12 & 9 & 84 & & $(0.089-0.704)$ \\
\hline \multicolumn{7}{|l|}{$\begin{array}{l}\text { Family involvement in } \\
\text { providing care }\end{array}$} \\
\hline Family involvement & 80 & 90 & 21 & 84 & 0.413 & 0.591 \\
\hline No family involvement & 9 & 10 & 4 & 16 & & $(0.166-2.107)$ \\
\hline \multicolumn{7}{|l|}{$\begin{array}{l}\text { Provision of Information } \\
\text { on Covid Prevention by } \\
\text { Midwives }\end{array}$} \\
\hline Well informed & 70 & 79 & 19 & 76 & 0.484 & 0.860 \\
\hline Not given information & 19 & 21 & 6 & 24 & & $(0.361-2.453)$ \\
\hline
\end{tabular}

In this study, the quality of ANC services was assessed with 10T ranging from Weight Measurement, Blood Pressure Measurement, Upper Arm Circumference Determination, Uterine Fundus Height, Fetal Location Determination and Listening to Fetal Heart Rate, Additional Blood Tablets, Tetanus Toxoid Immunization, Laboratory Tests, counseling and Management of cases. (Kementerian Kesehatan Republik Indonesia, 2019). Most of the service quality of ANC 10 T has not been carried out perfectly by $61.4 \%$ (70 people). However, if seen from the $7 \mathrm{~T}$, it has been carried out well. Midways often forget things like weighing the client, determining the circumference of the upper arm, determining the height of the uterine fundus, and TT immunization in the mother. Some of the respondents are doctor's clients who, in their examination, use ultrasound to assess the state of the fetus.

Lisa Marniyati, Irsan Saleh (2016) research on the quality of ANC services can improve early detection of distress signs, saying that not all midwives meet antenatal care 
standards. Some antenatal services that have not been implemented include anamnesis about the health history of pregnant women, counseling according to the needs of pregnant women, measurement of upper arm circumference, and measurement of height. At the same time, laboratory examination becomes an obstacle because of the rejection of some pregnant women (Marniyati, Saleh and Soebyakto, 2016).

The results of the bivariate analysis in this study stated that the quality of ANC services with the $10 \mathrm{~T}$ program affects the incidence of complications in pregnancy (p-value <0.05). Kassaw, Debie and Geberu (2020) said that the quality of maternity services should be applied both in infrastructure, implementation, and procedures. In carrying out anamnesis, physical examination procedures, laboratory examinations, and health counseling determine maternal health during pregnancy. The quality of ANC services can also be seen from pregnant women's compliance in making ANC visits to health service facilities and independent midwife practices. In this study, visits from pregnant women were seen according to gestational age and government programs, namely 4 ANC visits during the first semester to gestational age $(<12$ weeks $)$ at least once, during the second semester of pregnancy (12-24 weeks). At least once, and in semester 3, do it twice, namely at 2834 weeks and age 34 to 40 weeks (Kementerian Kesehatan Republik Indonesia, 2019).

However, in this study, there was no evidence of the influence of ANC visits on pregnancy complications ( $\mathrm{p}$ value $>0.05$ ) Another study explains that each pregnant woman needs at least four visits during pregnancy to maintain the quality of care and protection of pregnant women through early detection of risk factors, prevention, and management of complications (Marniyati, Saleh and Soebyakto, 2016). In other studies, it was found that most pregnant women continued to make ANC visits. Which were still carried out routinely using health protocols, namely wearing masks, making appointments when they wanted to visit, washing hands, and social distancing (Ariestanti, Widayati and Sulistyowati, 2020). Pregnant women who make visits ANC more than four times during their pregnancy will get 2.3 times the quality of service that is better than those who only do ANC once so that pregnant women will have their health monitored and immediately get treatment in case of complications in their pregnancy (Kassaw, Debie and Geberu, 2020). 
$\mathrm{MCH}$ handbook is a maternal and child health book used as a media and $\mathrm{MCH}$ service recording documents. This book is important for mothers and families to understand care during pregnancy, delivery, newborns, postpartum, and breastfeeding and can be used for birth control and monitoring of baby development (Kementerian Kesehatan RI, 2016). During the Covid-19 Pandemic, the $\mathrm{MCH}$ Handbook was very important because mothers could understand their health by understanding this $\mathrm{MCH}$ book, especially the signs of danger in pregnancy. The limitation of ANC examination during the Covid-19 pandemic is in the first trimester to detect risk factors or complications. The second trimester is done by telephoto communication, and the 3rd trimester is only used to prepare for childbirth. Ultrasound examinations and maternal classes were postponed until the pandemic ended or there was a decision from the government (Kementerian Kesehatan RI, 2020).

This study states that pregnant women who understand the contents of the $\mathrm{MCH}$ Handbook, especially in the pregnancy section, influence the incidence of complications during pregnancy ( $\mathrm{p}$-value <0.05). Ariestanti, Widayati and Sulistyowati (2020) said that mothers' knowledge affects mothers' behaviour in making ANC visits during the Covid-19 pandemic. The pregnant mother's understanding of the $\mathrm{MCH}$ handbook is related to the use of the $\mathrm{MCH}$ handbook. Likewise, the understanding of midwives as health workers in the $\mathrm{MCH}$ handbook correlates with the early detection of danger signs. It was also found that the involvement of the husband or family did not provide a positive correlation with the incidence of complications in pregnant women ( $\mathrm{p}$ value >0.05). Several studies suggest that family support will increase pregnant women's knowledge, attitudes, and behavior in detecting danger signs in pregnancy (Aditiawarman, Armini and Kristanti, 2008). The effect of providing Covid-19 prevention information with the incidence of complications in the mother was not found a positive correlation ( $\mathrm{p}$ value $>0.05$ ) in contrast to other studies on the provision of health education through what's app group about the knowledge of pregnant women in Simo Hospital in conducting early detection of preeclampsia that is positively correlated (Handayani and Milie, 2020). Similarly, health workers or counseling information about the danger signs is crucial to improve the mother's knowledge in detecting the presence of danger signs (Bililign and Mulatu, 2017). Health workers during the Covid-19 
pandemic must be able to carry out primary prevention through routine screening and isolation to reduce the spread of disease, using internet-based Counseling, Information and Education (IEC) techniques for pregnant women prone to complications and are infected with the coronavirus (Pradana, Casman and Nur'aini, 2020; Kementerian Kesehatan RI, 2020).

\section{CONCLUSION}

Most of the characteristics of pregnant women are healthy reproductive age at the age of 20 years to 35 years, high school education level, number of pregnancies 2 (first child and second child), and most of them work as housewives. The most complications of pregnant women in this study were anemia followed by hyperemesis gravidarum and about $8 \%$ of complications leading to Covid-19. Antenatal care services in independent practice midwives should use the 10T standard. Also, the midwives motivate pregnant women and their families to read and understand the contents of maternal and child health books, especially regarding the danger signs of pregnancy. So that complications that arise in pregnant women can be identified and managed correctly. In the end, it will help the government in reducing maternal and infant mortality.

\section{ACKNOWLEDGEMENT}

Researchers thank the Health Poltekkes Kemenkes Jakarta III, through the management and head of the research and community service unit center, who have supported this research. We also thank the midwife of Kopsah, SST., Midwife Cut Meliana Suri, Amd. Keb and midwife $\mathrm{Hj}$ Sutrianah, SST, which has helped a lot in data retrieval in this study and all parties involved.

\section{REFERENCES}

Achadi, E. L. (2019) Kematian Maternal dan Neonatal di Indonesia, Rakerkernas 2019. Tangerang.

Aditiawarman, Armini, N. K. A. and Kristanti, Y. I. (2008) 'Manfaat dukungan sosial keluarga pada perilaku antisipasi tanda bahaya kehamilan pada ibu primigravida', Jurnal Ners, 3(1).

Ariestanti, Y., Widayati, T. and Sulistyowati, Y. (2020) 'Determinan Perilaku Ibu Hamil Melakukan Pemeriksaan Kehamilan ( Antenatal Care ) Pada Masa Pandemi Covid -19', Jurnal Bidang Ilmu Kesehatan, 10(2), pp. 203-216. doi: https://doi.org/10.52643/jbik.v10i2.110 7.

Badan Pusat Statistik Provinsi DKI Jakarta (2019) Profil Kesehatan Provinsi DKI Jakarta 2019. Jakarta: Badan Pusat Statistik Provinsi DKI Jakarta.

Bililign, N. and Mulatu, T. (2017) 'Knowledge of obstetric danger signs and associated factors among reproductive-age women in Raya Kobo district of Ethiopia: A communitybased cross-sectional study', BMC Pregnancy and Childbirth, 17(1), pp. 
$1-7$.

https://doi.org/10.1186/s12884-0171253-4.

Budhi, N. G. M. A. A. and Nurhayati, T. (2020) 'Effectiveness of Guidance For Pregnant Women About Early Detection of Danger Signs in Pregnancy Using Leaflet and Audiovisual Media', Jurnal Riset Kesehatan Poltekkes Depkes Bandung, 12(1), pp. 1-11. doi: https://doi.org/10.34011/juriskesbdg.v $12 \mathrm{i} 1.886$.

Ermalena, M. (2017) Indikator Kesehatan SDGs Di Indonesia, Diskusi Panel Pengendalian Tembakau dan Tujuan Pembangunan Indonesia. doi: https://doi.org/10.1007/BF01886316.

Handayani, S. and Milie, P. (2020) 'Pengaruh Pendidikan Kesehatan Melalui WhatsApp Group terhadap Pengetahuan dan Sikap Ibu Hamil dalam deteksi Dini Preeklamsia Pada masa pandemi Covid-19', Jurnal Kebidanan, 12(2), pp. 199-212. doi: https://doi.org/10.18502/kls.v4i13.526 1 .

Jewaro, M. et al. (2020) 'Knowledge of obstetric danger signs and associated factors: a study among mothers in Shashamane town, Oromia region, Ethiopia', Reproductive health. Public Health Reviews, 17(1), p. 4. doi: https://doi.org/10.1186/s12978-0200853-z.

Kassaw, A., Debie, A. and Geberu, D. M. (2020) 'Quality of Prenatal Care and Associated Factors among Pregnant Women at Public Health Facilities of Wogera District, Northwest Ethiopia', Journal of Pregnancy, 2020, pp. 1-8. doi:

https://doi.org/10.1155/2020/9592124.

Kementerian Kesehatan Republik Indonesia (2019) Profil Kesehatan Indonesia 2018. Jakarta: Kementerian
Kesehatan RI.

Kementerian Kesehatan RI (2016) Petunjuk Teknis Penggunaan Buku Kesehatan Ibu dan Anak. Jakarta: Kementerian Kesehatan RI dan JICA.

Kementerian Kesehatan RI (2020) Pedoman Bagi Ibu Hamil, Ibu Nifas, dan Bayi Baru Lahir Di Era Pandemi Covid-19. Jakarta: Direktorat Jenderal Kesehatan Masyarakat Kementerian Kesehatan RI.

Marniyati, L., Saleh, I. and Soebyakto, B. B. (2016) 'Pelayanan Antenatal Berkualitas dalam Meningkatkan Deteksi Risiko Tinggi pada Ibu Hamil oleh Tenaga Kesehatan di Puskesmas Sako, Sosial, Sei Baung dan Sei Selincah di Kota Palembang', Jurnal Kedokteran dan Kesehatan, 3(1), pp. 355-362.

Masturoh, Respatih, S. H. and Murti, B. (2017) 'Path Analysis Risk Factors that Influence Maternal Mortality in District of Brebes', Journal of Maternal and Child Health, 2(1), pp. 11-19. doi: https://doi.org/10.26911/thejmch.2017. 02.01.02.

Nurhidajat, A. and Kusumawati, D. (2018) 'Efektivitas Pelaksanaan Percepatan Penurunan Angka Kematian Ibu ( AKI ) Di Indonesia', Jurnal Sistem Penganggaran Sektor Publik, 2(1), pp. 1-28. doi: https://doi.org/10.33827/akurasi2018.v ol2.iss1.art32.

Pradana, A. A., Casman, C. and Nur'aini, N. (2020) 'Pengaruh Kebijakan Social Distancing pada Wabah COVID-19 terhadap Kelompok Rentan di Indonesia', Jurnal Kebijakan Kesehatan Indonesia: JKKI, 9(2), pp. 61-67. doi: https://doi.org/10.22146/jkki.55575. 
125 Jurnal Ilmu dan Teknologi Kesehatan, Vol.9, No.1, Sept 2021, pp: 111-125

Putri, D. P. K. and Lestari, S. (2015) 'Pembagian Peran Dalam Rumah Tangga pada pasangan suami istri Jawa', Jurnal Penelitian Humaniora, 16(1), pp. 72-85. doi: https://doi.org/10.23917/humaniora.v1 $6 i 1.1523$.
Sulastri et al. (2019) 'Contribution to the Number of Pregnancy (Gravida) Complications of Pregnancy and Labor', KnE Life Sciences, 4(13), pp. 316-325. doi: https://doi.org/10.18502/kls.v4i13.526 1. 